\title{
Assessment of Pageantries: Learning or Enjoying?
}

\author{
Victor William B. Salazar ${ }^{1 \#}$ \& Jerald C. Moneva ${ }^{2}$ \\ 1,2 Jagobiao National High School, Jagobiao, Mandaue City, Cebu, Philippines. \\ \# corresponding author \\ Type of Work: Peer-Reviewed \\ DOI: http://dx.doi.org/10.21013/jems.v16.n2.p1
}

\section{How to cite this paper:}

Salazar, V.W.B., Moneva, J.C. (2020). Assessment of Pageantries: Learning or Enjoying?. IRA International Journal of Education and Multidisciplinary Studies (ISSN 2455-2526), 16(2), 84-95. doi: http://dx.doi.org/10.21013/jems.v16.n2.p1

(C) Institute of Research Advances.

This work is licensed under a Creative Commons Attribution-Non Commercial 4.0 International License subject to a proper citation to the publication source of the work.

Disclaimer: The scholarly papers as reviewed and published by the Institute of Research Advances (IRA) are the views and opinions of their respective authors and are not the views or opinions of the IRA. The IRA disclaims of any harm or loss caused due to the published content to any party.

Institute of Research Advances is an institutional publisher member of Publishers International Linking Association Inc. (PILA-CrossRef), USA. The institute is an institutional signatory to the Budapest Open Access Initiative, Hungary advocating the open-access of scientific and scholarly knowledge. The Institute is a registered content provider under Open Access Initiative Protocol for Metadata Harvesting (OAI-PMH).

The journal is indexed \& included in WorldCat Discovery Service (USA), CrossRef Metadata Search (USA), WorldCat (USA), OCLC (USA), Open J-Gate (India), EZB (Germany) Scilit (Switzerland), Airiti (China), Bielefeld Academic Search Engine (BASE) of Bielefeld University, Germany, PKP Index of Simon Fraser University, Canada. 


\begin{abstract}
Pageantries, as defined connotatively, are events or outdoor performances consisting of a procession of people in elaborate costumes and attires. Beauty pageants, which often occur in schools during culminating activities, immensely help students gain a wider point of view towards education and can also be enjoyable at the same time. However, there are still plenty of students who tend to infer these events as leisure activities or sources for enjoyment. The main goal of the study is to determine which will transpire more between learning and enjoying, to do so, the researcher used the quantitative - correlational approach. To obtain the best responses possible, the chosen respondents for the study were the Grade 10 and the Senior High School students of Jagobiao National High School. The researcher first explained the purpose of the study and then assured the respondents that the data gathered will only be for research purposes. The researcher then distributed the survey questionnaires and collected them back after the given time limit. With proper analysis and interpretation of the data, it was determined that there is no significant relationship between the variables. However, pageantries offer students a unique experience and opportunity to gain more knowledge.
\end{abstract}

Keywords: Pageantries, Learning, Enjoying

\title{
Introduction
}

Pageants are public events or outdoor performances consisting of a procession of people in elaborate, colorful costumes (Merriam - Webster's Dictionary, 2019). Such contests incorporate personality, talent, and answers to judges' questions as per judged criteria (Definitions.net, 2019). Here in school, different grade levels have extracurricular activities. They include, but are not limited to activities such as stage plays, beauty pageants, talent competitions, entertainment, variety shows, and the like. These events promote self-confidence, instill discipline, commitment, a healthy respect for oneself and give students a more holistic approach towards education. With that being said, still there are plenty of students who tend to infer the event as just a leisure activity.

Here in Jagobiao National High School, students must understand that engaging themselves in extracurricular activities, beauty pageants to be particular, which often take place in school campus during culminating activities, immensely help them in gaining a wider point of view towards education while attaining invaluable experiences which students cannot get from rigorous readings and quizzes inside the classroom. As the event progresses, entertaining performances are integrated into the activity to amuse and attract the students especially those who have yet to appreciate pageantries. Even so, there are still a lot of students who lack the understanding of why such activities are encouraged.

Most women, upon experiencing or attending pageants, found the opportunity to build or rebuild confidence, increase self - esteem, and even found a new sense of empowerment [2]. From a theoretical perspective, a link has been found between women's pageant experiences helping them meaningfully in terms of fluency in speaking, competence \&quality traits [1]. As discussed already from the articles above, those who have experienced attending in pageantries, acquired fundamental skills useful in later professional environment and helped them demonstrate abilities that were much better than the average graduate. Savoring the moment and healthy emotions drawn from attending these performances amplify the level of a person's mindfulness/awareness greatly and concludes that if we enjoy the process, we are more likely to perform well[28].

In this paper, the researcher discusses if enjoyment in pageantries determines the learning of the students.

\section{Statement of the Problem}

The researcher intends to understand whether pageantries are determiners of learning or enjoying. To what extent do students feel about learning towards pageants. To what extent do students enjoy pageantries in the school. Do pageantries evoke more learning than enjoyment?

\section{Hypothesis:}

H0: There is no significant relationship between the two variables 
H1: There is a significant relationship with the two variables

\section{Review of Related Literature}

\section{Pageantries}

From a theoretical perspective, the findings reveal a link between women's pageant experiences helping them significantly especially in fields like communication, competence, and soft skills [1]. Respondents, mostly women, that upon experiencing or attending beauty pageants, found the opportunity to build or rebuild confidence, increase self - esteem and found a new sense of empowerment [2]. During their learning programs, students who were engaged in speaking English had no difficulties with speaking/conversing with others [3].

\section{Extra-Curricular Activities}

Study shows that in involving oneself in extracurricular activities (ECA) may somehow be important in fostering school connectedness, hence the findings show that participation in ECA is associated with greater attachment in school than not participating in these activities [4]. Extracurricular activity participants had better grades, higher self - concept, and educational attainment. Also, students often gained professional skills needed at work[5]. Students who have the potential in performing activities tend to perform better at school [6]. Those who participated in extracurricular activities had significant increases in their overall performances, specifically their GPA compared to non - participants [7]. Participating in extracurricular activities can benefit the student/child's lives instead of ruining it [8]. Students who prove to have professional skills in leadership had experienced many opportunities joining organizations, clubs, and ECA [9]. Graduates who excelled in ECA, prove to have greater chances of gaining worthwhile employment [10]. Extracurricular activities offer the opportunity to engage the student into groups of interacting people, which stimulates great development in their interpersonal skills particularly in their psychological and intellectual fields [11]. ECA is said to equip students to/in becoming well - rounded, balanced, and experienced by supplementing learning with integrating knowledge and carrying out tasks to accomplish objectives [12]. The positive developments in extracurricular activities are found commonly in the "contents" of the activities, mainly more on attitude, discipline, and practices [13]. Extracurricular activities had helped contribute progress in the students' physical, mental, social, and emotional development [14]. Involvement in ECA, desire to pursue greater heights, specific learning preferences mainly contribute to students' improvement in academic performance [15]. Student's involvement in learning is reflected based on the process. So, to achieve the desired goal, teachers were suggested to provide learning opportunities intertwined with designed educational activities (ECA) to attract students and make them be active learners who interact with the environment [16]. The study suggests that universities should provide activities that make them interact with the environment and make them experience both formal curriculum and extracurricular activities [17]. ECA has both positive and negative effects on the students' academic performance. Direct academic progress while others devoted more time to ECA at the expense of their studies [18]. ECAs are activities that apply learning while having fun [19]. However, a separate study shows extracurricular activities had no significant effect on the students' academic performance [20]. Besides, some students 'over engagement in ECA or excessive focus to those activities they were interested to get involved in takes more of their time for practice instead of doing their classroom responsibilities [21].

\section{Co-Curricular Activities}

Most of the subjects responded that they were interested in having an understanding of cocurricular activities (CCA), therefore, the researcher suggested that having CCA in schools/curriculums is essential [22]. Respondents who involve themselves in co-curricular activities were more self - efficient and motivated in both internal and external activities. [23]. Participation in co-curricular activities showed positive effects on the academic performance of the students [24]. Co-curricular activities had proven to raise the academic performances of the secondary level and concluded that there is a positive relationship between CCA and the students' studies [25]. Both male and female students who participated in various CCA have shown an even better performance inside the classroom compared to their non - participating counterparts [26]. 


\section{Enjoyment}

Adolescents participating in art, sports, and/or social groups had shown better people skills and resilience in comparison to those who do not belong to any group [27]. Results significantly show that the relation between savoring the moment and healthy emotions amplify the level of a person's mindfulness/awareness greatly [28]. Reality programs true nature is for enjoyment, but at the same time encourages the audience to think and talk about it, which exercises the brain and may somehow learn something from it [29].

\section{Research Methodology}

This chapter contains the study design, locale, instrument, respondents, and data gathering procedure.

\section{Design of the Study}

The research design is a quantitative approach survey. The researchers used this design to determine which will transpire more, learning or enjoyment?

\section{Environment}

The study was conducted inside the campus of Jagobiao National High School and on the students at different levels. The institution consists of six buildings - four buildings for the junior high and two for the senior high school department. Three buildings located at the upper part and the other three at the lower portion of the campus.

\section{Respondents}

The respondents of the study covered the Grade 10 and the Senior High School students of Jagobiao National High School. The Grade 10 are divided into two schedules: The Day (Morning) Class students and the Night Class students with 5 sections each namely: Diamond, Topaz, Amethyst, Sapphire and Quartz. The Senior High School offers 5 strands, in grade 11 there are: Humanities and Social Sciences (HUMSS), General Academic Strand (GAS), Accountancy and Business Management (ABM), Technical Vocational Learning (TVL) and Science, Technology, Engineering and Mathematics (STEM). In grade 12 there are only 3 strands: Humanities and Social Sciences (HUMSS), Accountancy and Business Management (ABM), and the General Academic Strand (GAS).

\section{Instrument}

The researchers intended to use a survey-type questionnaire as the instrument for this study. Two variables are being examined - Learning and Enjoying. Enjoyment as a stand-alone variable while Learning is broken down into three sub-types, namely; Knowledge, Behavioral, and Psychomotor. A Likert Scale checklist type of questionnaire is used to determine the level of responses for each variable. The respondents will then be asked to place a checkmark on the answer that best describes their opinion. The choices are (5) - Strongly Agree, (4) - Agree, (3) Average, (2) - Disagree, and (1) - Strongly Disagree. A set of indicators for each variable is made up of 5 questions. The sum of each result will be categorized into, 1 - 5 ( 1 - Strongly Disagree), 6 - 10 (2 - Disagree), 11 - 15 (3 - Average), 16 - 20 (4 - Agree) \& 21 25 (5 - Strongly Agree).

\section{Data Gathering}

To conduct this study, the researchers first secured permission and authorization from the Principal. Upon approval, the researchers then obtained a list of students per classroom that is within the study's scope. Afterward, data gathering was done by administering the survey questionnaires and collected after the given time limit. The raw data was subsequently collated and the appropriate statistical method was used to analyze and interpret the data. 
IRA-International Journal of Education $छ$ Multidisciplinary Studies

PRESENTATION, ANALYSIS AND INTERPRETATION OF DATA

TABLE 1.COGNITIVE LEARNING

\begin{tabular}{lcc}
\hline Indicators & Mean & Interpretation \\
\hline $\begin{array}{l}\text { 1. Pageantries catch the attention of the audience with a variety of images that } \\
\text { somehow shape my opinion on similar issues. }\end{array}$ & 3.46 & Agree \\
$\begin{array}{l}\text { 2. Watching pageants exercises my way of expressing my words especially when } \\
\text { introducing myself. }\end{array}$ & 3.48 & Agree \\
$\begin{array}{l}\text { 3. Pageantry themes open up my mind to new ideas that come in handy in } \\
\text { dealing with some related life situations. }\end{array}$ & 3.52 & Agree \\
$\begin{array}{l}\text { 4. Some questions during Q and A portions of pageantries are so engaging such } \\
\text { that I silently tend to come up with my answer during the event and recall some } \\
\text { unforgettable scenes even after the show. }\end{array}$ & 3.55 & Agree \\
$\begin{array}{l}\text { 5. Lessons on facts and figures during Q and A portions often come useful at } \\
\text { future discussions with other people. }\end{array}$ & 3.59 & Agree \\
\hline Weighted Mean: & 3.52 & Agree \\
\hline
\end{tabular}

Scaling: 1.00-1.80 (Strongly Disagree), 1.81-2.60 (Disagree), 2.61-3.40 (Average), 3.41-4.20 (Agree), 4.21-5.00 (Strongly Agree)

Table 1shows the three highest weighted mean under Cognitive Learning were interpreted as "Agree". The indicator, "Lessons on facts and figures during Q and A portions, often come useful at future discussions with other people" with a mean of 3.59, means that students can relate the knowledge they gained in pageantries to possible future discussions. The indicator, "Some questions during Q and A portions of pageantries are so engaging such that I silently tend to come up with my answer during the event and recall some unforgettable scenes even after the show" with a mean of 3.55, implies that the event caught the respondents' full attention and stimulated their thinking and memory retention. The indicator, "Pageantry themes open up my mind to new ideas which come in handy in dealing with some related life situations" with a mean of 3.52 indicates that the experience sparks inductive reasoning which is a higher level of thought process that enables them to adapt better in some future life situations.

The remaining two have the lowest weighted mean. The indicator, "Pageantries catch the attention of the audience with a variety of images which somehow shape my opinion on similar issues" with a mean of 3.46 , refers to activating one's mental activity on processing both visual images of the physical environment of the pageantry as well as logic and images that are being created in one's mind in the course of experiencing the event. Lastly, the indicator, "Watching pageants exercises my way of expressing my words especially when introducing myself" with a mean of 3.48, refers to a learning phenomenon wherein the subject mentally simulates himself doing the desired action by watching role models or actors deliver the same activity.

The researchers have observed that in pageantry events, selective learning is evident among the students, they tend to be not participative most of the time and pay attention only to what catches their interest. Study shows that involving oneself in extracurricular activities (ECA) may somehow be important in fostering school connectedness, hence the findings show that participation in ECA is associated with greater attachment with the school than not participating in these activities [4]. Extra - curricular activity participants had better grades, higher self - concept, and educational attainment. Besides, students often gained professional skills needed in work[5].

\section{TABLE 2. AFFECTIVE/BEHAVIORAL}

\begin{tabular}{lcc}
\hline Indicators & Mean & Interpretation \\
\hline $\begin{array}{l}\text { 1. The lessons I learned by experiencing pageantries in a way serve as a guide } \\
\text { in becoming a better person. }\end{array}$ & 3.42 & Agree \\
$\begin{array}{l}\text { 2. The learnings I get from attending pageantries help me develop a positive } \\
\text { attitude towards myself and other people. }\end{array}$ & 3.50 & Agree \\
$\begin{array}{l}\text { 3. Beauty pageants taught me how to be more cautious and assertive. } \\
\begin{array}{l}\text { 4. Stage shows and other pageantries make me reflect on my need to improve } \\
\text { Agree }\end{array}\end{array}$ & 3.43 & Agree
\end{tabular}


on my skills.

5. the remarkable performance demonstrated by individuals during pageantries through hard work and dedication draws admiration from the audience.

Weighted Mean: 3.56 Agree

Scaling: 1.00-1.80 (Strongly Disagree), 1.81-2.60 (Disagree), 2.61-3.40 (Average), 3.41-4.20 (Agree), 4.21-5.00 (Strongly Agree)

Table 2 shows that 5 of the indicators under Affective/Behavioral have weighted mean that were all interpreted as Agree. The indicator - "The remarkable performance demonstrated by individuals during pageantries through hard work and dedication draws admiration from the audience", with a mean of 3.56reflects the subjects' emotional feelings in response to the qualities demonstrated by the participants. The indicator - "The learnings I get from attending pageantries help me develop a positive attitude towards myself and other people", with a mean of 3.50, implies that the experience of attending pageantries elicits a general positive impression and to some extent - a new insight about oneself and towards other individuals. Next, the indicator - "Stage shows and other pageantries make me reflect on my need to improve on my own skills" with a mean of 3.47 brings the respondent to compare his/her abilities with those of the performers, accepts his/her deficiency and considers the necessity for self-adjustment.

The two other indicators examined under this variable have the lowest weighted mean yet still fall within significant levels. The indicator - "The lessons I learned by experiencing pageantries in a way serve as a guide in becoming a better person" with a mean of 3.42, suggests that the learnings gained in attending pageantries are somehow useful in one's endeavor towards self-actualization. Finally, the indicator "Beauty pageants taught me how to be more cautious and assertive", with a mean of 3.43 indicates that participating or observing beauty pageants enhances the ability to assert oneself as well as improve one's social awareness.

The positive developments found in extracurricular activities are found commonly in the "contents" of the activities, mainly more on attitude, discipline, and practices [13].ECA is said to equip students in becoming well - rounded, balanced, and experienced by supplementing learning with integrating knowledge and carrying out the objectives [12]. Extra - curricular activities offer the opportunity to engage the student into groups of interacting people, which stimulates great development in their interpersonal skills particularly in their psychological and intellectual fields [11].

TABLE 3.PSYCHOMOTOR LEARNING

\begin{tabular}{lrc}
\hline Indicators & Mean & Interpretation \\
\hline $\begin{array}{l}\text { 1. Pageants can help develop one's listening skills and fluency in speaking. } \\
\text { 2. Watching performers do their act or deliver their presentation help me develop } \\
\text { patterns and movements that I can familiarize myself with to improve how I }\end{array}$ & 3.63 & Agree \\
$\begin{array}{l}\text { express myself in front of other people. } \\
\text { 3. I sing along, follow or imitate hand movements of the performers during the } \\
\text { presentation of talents. }\end{array}$ & 3.63 & Agree \\
$\begin{array}{l}\text { 4. Acting out a role from a specific part of a presentation is one thing I learned } \\
\text { from pageantry performers. }\end{array}$ & 3.41 & Agree \\
$\begin{array}{l}\text { 5. Watching some pageantry events enable me to learn body movement skills or } \\
\text { techniques useful to what sport I am into. }\end{array}$ & 3.38 & Average \\
\hline Weighted Mean: & 3.41 & Agree \\
\hline
\end{tabular}

Scale: 1.00-1.80 (Strongly Disagree), 1.81-2.60 (Disagree), 2.61-3.40 (Average), 3.41-4.20 (Agree), 4.215.00 (Strongly Agree)

Table 3underPsychomotor Skills shows indicators 1 and 2 have the same highest weighted mean of 3.63. Indicator 1. -"Pageantries can help develop one's listening skills and fluency in speaking", simply indicates that when one is engrossed at something that he/she is interested in, the tendency is to listen more closely and attentively, thus, "the skill to do comes from the doing". Indicator 2. -"Watching performers do 
their act or deliver their presentation, help me develop patterns and movements that I can familiarize myself with to help improve how I express myself in front of other people likewise means learning is possible by watching. The indicator, "Acting out a role from a specific part of a presentation is one thing I learned from pageantry performers" with a mean of 3.38 falls within an average rating. This indicator focuses on the observation skills of the respondents and their ability to turn their mental learning into a kinesthetic activity. The following two indicators have the same weighted mean of 3.41: Indicator 3. - "I sing along, follow or imitate hand movements of the performers during the presentation of talents", shows that there is evidence of psychomotor learning skills in pageants like the imitative actions made by the audience. Lastly, indicator 5. - "Watching some pageantry events enables me to learn body movement skills or techniques useful in the sport I am into", determines that the respondents have gained significant psychomotor skills from watching pageantries which can be applied to the sport activity they are into. The researchers have observed that several students do actively imitate, move around and follow participants movements in pageantries.

In a related study, students who have potential in performing activities tend to perform better at school [6]. Those who participated in extracurricular activities had significant increases in their overall performances, specifically their GPA compared to non - participants [7].

\section{TABLE 4. ENJOYMENT IN PAGEANTRIES}

\begin{tabular}{lcc}
\hline Indicators & Mean & Interpretation \\
\hline 1. I somehow get relieved from worries, stress, and anxieties when I watch & & \\
pageantries. & 3.41 & Agree \\
2. My mood changes and I start feeling excited, interested, and enthusiastic. & 3.53 & Agree \\
3. It amuses me when I visualize my self-partaking in such events. & 3.41 & Agree \\
4. I am delighted to find out the different skills and abilities of each contestant. & 3.42 & Agree \\
5. I am thrilled and anticipate new ideas to learn from pageantries. & 3.44 & Agree \\
\hline Weighted Mean: & 3.44 & Agree \\
\hline
\end{tabular}

Scaling: 1.00-1.80 (Strongly Disagree), 1.81-2.60 (Disagree), 2.61-3.40 (Average), 3.41-4.20 (Agree), 4.21-5.00 (Strongly Agree)

The above table shows the weighted mean of all 5 indicators under enjoying in Pageantries were interpreted as Agree. Indicator 2, with the highest mean of 3.53 - "My mood changes and I start feeling excited, interested and enthusiastic", denotes watching pageants bring positive emotions/feelings to the audience. Indicator 5. - "I am thrilled and anticipate new ideas to learn from pageantries" with a mean of 3.44 , implies that there is a considerable level of excitement among the audience during pageantries. In indicator 4. - "I am delighted to find out the different skills and abilities of each contestants", with a rate of 3.42 , confirms the significant level of enjoyment of the audience watching the different skills performed by the participants. The two indicators with a lowest weighted mean of 3.41 still fall within significant values, these are Indicator 1. - "I somehow get relieved from worries, stress, and anxieties when I watch pageantries", confirms that somehow the audience does tend to feel relieved of their worries while watching pageantries, though just for fleeting moments, and lastly, Indicator 3. - "It amuses me when I visualize my self-partaking in such events", affirms there is some satisfaction or amusement effect to the respondents when they venture at imagining themselves in place of the performers doing the same activities.

Students generally like and enjoy pageantries. Studies significantly show the relation between savoring the moment and healthy emotions amplify the level of a person's mindfulness/awareness greatly [28]. Related literature shows ECAs are activities that apply learning while having fun [19]. 
TABLE 5. ENJOYMENT AND COGNITIVE LEARINNG

Cognitive Learning

\begin{tabular}{|c|c|c|c|c|c|c|c|}
\hline & & $\begin{array}{c}\text { No significant } \\
\text { learning }\end{array}$ & $\begin{array}{c}\text { Few } \\
\text { significant } \\
\text { learning }\end{array}$ & $\begin{array}{c}\text { Fair } \\
\text { significant } \\
\text { learning }\end{array}$ & $\begin{array}{c}\text { Moderate } \\
\text { significant } \\
\text { learning }\end{array}$ & $\begin{array}{c}\text { Great } \\
\text { significant } \\
\text { learning }\end{array}$ & Total \\
\hline & Did not enjoy & 2 & 0 & 5 & 4 & 0 & 11 \\
\hline $\begin{array}{l}\text { Enjoying in } \\
\text { Pageantries }\end{array}$ & Slightly enjoyed & 0 & 2 & 75 & 243 & 30 & 350 \\
\hline & Fairly enjoyed & 0 & 0 & 1 & 36 & 16 & 53 \\
\hline Total & & 2 & 2 & 81 & 283 & 46 & 414 \\
\hline
\end{tabular}

Table 5 shows a cross-tabulation of Enjoyment in Pageantries and Cognitive Learning. The students' response to the indicators clearly shows that they have acquired learning and have as well enjoyed their pageant experiences both at varying degrees. Of the 414 respondents, 350 (moderately) +53 (fairly) enjoyed the experience. Overall, a very high number of respondents (412) manifest that they have picked up learnings from pageantries, while (403) enjoying their experience. This further confirms the study that... ECAs are activities that apply learning while having fun [19]. Another study concurs - reality programs' true nature is for enjoyment, but at the same time encourages the audience to think and talk about it, which exercises the brain and may somehow learn something from it [29].

TABLE 6. ENJOYMENT AND AFFECTIVE/BEHAVIORAL

Affective/Behavioral

\begin{tabular}{llcccccc}
\hline & $\begin{array}{c}\text { Not } \\
\text { affected }\end{array}$ & $\begin{array}{c}\text { Slightly } \\
\text { affected }\end{array}$ & $\begin{array}{c}\text { Fairly } \\
\text { affected }\end{array}$ & $\begin{array}{c}\text { Moderately } \\
\text { affected }\end{array}$ & $\begin{array}{c}\text { Greatly } \\
\text { affected }\end{array}$ & Total \\
\hline & Did not enjoy & 1 & 5 & 3 & 2 & 0 & $\mathbf{1 1}$ \\
$\begin{array}{l}\text { Enjoyment } \\
\text { in }\end{array}$ & $\begin{array}{l}\text { Slightly } \\
\text { enjoyed }\end{array}$ & 0 & 6 & 100 & 213 & 31 & $\mathbf{3 5 0}$ \\
& Fairly enjoyed & 0 & 0 & 1 & 26 & 26 & $\mathbf{5 3}$ \\
\hline Total & & $\mathbf{1}$ & $\mathbf{1 1}$ & $\mathbf{1 0 4}$ & $\mathbf{2 4 1}$ & $\mathbf{5 7}$ & $\mathbf{4 1 4}$ \\
\hline
\end{tabular}

Table 6 presents the cross-tabulation of Enjoyment in Pageantries and Affective/Behavioral. 403 of the 414 respondents variably enjoyed the experience while 413 out of 414 respondents validate their behavior was affected at varying degrees. This shows there is a high number of respondents who manifested that pageants significantly affect their behavior while enjoying their experience. Respondents, mostly women, that upon experiencing or attending beauty pageants, found the opportunity to build or rebuild confidence, increase self - esteem and found a new sense of empowerment [2].Extracurricular activities offer the opportunity to engage the student into groups of interacting people, which stimulates great development in their interpersonal skills [11]. 
TABLE 7. ENJOYMENT AND PSYCHOMOTOR LEARNING

Psychomotor Learning

\begin{tabular}{|c|c|c|c|c|c|c|c|}
\hline & & $\begin{array}{l}\text { No skills } \\
\text { developed }\end{array}$ & $\begin{array}{l}\text { Few skills } \\
\text { developed }\end{array}$ & $\begin{array}{l}\text { Fair skills } \\
\text { developed }\end{array}$ & $\begin{array}{l}\text { Moderate } \\
\text { significant } \\
\text { skills } \\
\text { developed }\end{array}$ & $\begin{array}{c}\text { Great } \\
\text { significant } \\
\text { skills } \\
\text { developed }\end{array}$ & Total \\
\hline \multirow{4}{*}{$\begin{array}{l}\text { Enjoying } \\
\text { in } \\
\text { Pageantries }\end{array}$} & Did not enjoy & 3 & 6 & 1 & 1 & 0 & 11 \\
\hline & $\begin{array}{l}\text { Slightly } \\
\text { enjoyed }\end{array}$ & 1 & 238 & 48 & 50 & 13 & 350 \\
\hline & & & & & & & \\
\hline & Fairly enjoyed & 1 & 20 & 17 & 4 & 11 & 53 \\
\hline Total & & 5 & 264 & 66 & 55 & 24 & 414 \\
\hline
\end{tabular}

Table 7 shows the cross-tabulation of Enjoyment in Pageantries and Psychomotor Learning. The table indicates that the students have variably developed psychomotor skills while enjoying their pageant experience. Of the 414 respondents, 350 (slightly) +53 (fairly) enjoyed the spectacle of pageants. The study also shows a total of 409 out of 414 respondents manifested psychomotor skills being developed at varying levels and attribute this to their experience at pageantries. During learning programs, students who were regularly engaged in speaking English had no difficulties on conversing with others [3]. Extra curricular activities had helped contribute progress in the students' physical, mental, social, and emotional development [14].

TABLE 8. ENJOYMENT VIS-A'-VIS LEARNING IN TERMS OF COGNITIVE, AFFECTIVE \& PSYCHOMOTOR

\begin{tabular}{|c|c|c|c|c|c|}
\hline LAMBDA & & Value & $\begin{array}{c}\text { Asymp. Std. } \\
\text { Error }^{\mathrm{a}}\end{array}$ & $\begin{array}{c}\text { Approx. } \\
\mathrm{T}^{\mathrm{b}}\end{array}$ & $\begin{array}{c}\text { Approx. } \\
\text { Sig. }\end{array}$ \\
\hline \multirow[t]{3}{*}{ Cognitive } & Symmetric & .015 & .017 & .905 & .365 \\
\hline & $\begin{array}{l}\text { Enjoyment } \\
\text { Dependent }\end{array}$ & .031 & .022 & 1.418 & .156 \\
\hline & $\begin{array}{l}\text { Cognitive } \\
\text { Dependent }\end{array}$ & .008 & .023 & .333 & .739 \\
\hline \multirow[t]{3}{*}{ Affective } & Symmetric & .017 & .012 & 1.418 & .156 \\
\hline & $\begin{array}{l}\text { Enjoyment } \\
\text { Dependent }\end{array}$ & .016 & .016 & 1.001 & .317 \\
\hline & $\begin{array}{l}\text { Affective } \\
\text { Dependent }\end{array}$ & .017 & .015 & 1.136 & .256 \\
\hline \multirow[t]{3}{*}{ Psychomotor } & Symmetric & .009 & .009 & 1.001 & .317 \\
\hline & $\begin{array}{l}\text { Enjoyment } \\
\text { Dependent }\end{array}$ & .031 & .031 & 1.001 & .317 \\
\hline & $\begin{array}{l}\text { Psychomotor } \\
\text { Dependent }\end{array}$ & .000 & .000 &.$^{\mathrm{c}}$ &.$^{\mathrm{c}}$ \\
\hline
\end{tabular}


If Cognitive Learning is held independently, students' Enjoyment in Pageantries is (.031). while if Enjoyment in Pageantries is held independent, Cognitive Learning of students is (.008). Both values are very small which clearly shows no correlation at all. The two variables - Enjoyment in Pageantries (.156) and Cognitive Learning (.739) far exceed the significant alpha (.05) which means that the study has failed to reject the null hypothesis. The association between students' Enjoyment in Pageantries and Cognitive Learning revealed that only $3.1 \%$ expresses that to enjoy in pageants is the major reason why they choose to attend. While about only $0.8 \%$ expressed that they have picked up significant learnings in pageants. ECA had both positive and negative effects on the students' academic performance. Direct academic progress while others devoted more time to ECA at the expense of their studies [18].Extracurricular activities had no significant effect on the students' academic performance [20].

If the Affective Learning value is held independent, students' Enjoyment in Pageantries is (.016), while if Enjoyment in Pageantries is held independent, the Affective Learning of the students is (.017) both values are very minimal so it can be considered that there is no correlation at all between them. The two variables, Enjoyment in Pageantries (.317) and Affective/Behavioral (.256) exceed the alpha value (.05), which means that the study has failed to reject the null hypothesis. The relation between students' Enjoyment in Pageantries and Affective/Behavior revealed only 1.6\% expressed that they enjoyed being present at pageants.

About $1.7 \%$ expressed that they have concrete and positive developments in their behavior. Results showed that Enjoyment in Pageantries has no significant relation with the Affective/Behavior of the respondents.

If Psychomotor Learning is held independent, students' Enjoyment in Pageantries is (.031) while if Enjoyment in Pageantries is held independent, Psychomotor Learning of the students is constant at (.000). Enjoyment in Pageantries' value is very small, and with a constant value for Psychomotor Learning, the result can simply be interpreted as "no correlation at all". The two variables, Enjoyment in Pageantries (.317) and Psychomotor Learning (.000) does not exceed the alpha value (.05). which means that the study has failed to reject the null hypothesis. Students' Enjoyment in Pageantries and Psychomotor Learning revealed that only $3.1 \%$ expressed that instead of developing skills while watching, they were more focused on having fun. Meanwhile Psychomotor Learning remained a constant value, meaning that students' responses resulted in a classification of "no correlation at all". Students' level of engagement in ECA, were only those they were interested to get involved in [21]. Student's involvement in learning is reflected based on the process. So, to achieve the desired goal, teachers were suggested to provide learning opportunities intertwined with designed educational activities (ECA) to attract students and make them be active learners who interact with the environment [16].

\section{SUMMARY OF FINDINGS, CONCLUSIONS, AND RECOMMENDATIONS}

This chapter presents the summary and the major findings of the study. Based on these findings, the conclusion was made and recommendations were suggested. The purpose of this study is to determine the various factors of pageantries whether it can give knowledge to the students or just enjoyment.

\section{Summary of Findings}

Based on the overall weighted mean results, the three learning variables considered in this study, namely - Knowledge, Affective \&Psychomotor indicate a significant level of learning among the participants and attendees. Likewise, this study indicates that the students show a significant level of enjoyment in pageantries.

Based on the results, pageantries are significant determinants of both learning and enjoying. While both variables are quite similar in intensity, the results also show that there is no significant relationship between the two. One exists independently from the other. 


\section{Conclusion}

Pageantries offer a different kind of learning experience, one that combines learning and enjoying yet integrates both classroom lessons and insights on our culture and society, etc. More often it imbues an individual with a greater sense of self by acquiring a fresh new perspective on the subject matter through a whole new stimulating experience.

Therefore, pageantry should continually be used and promoted in schools as a powerful aid or method in learning with even more innovation and creativity.

\section{Recommendations}

Based on the study conducted, the researcher recommends the following:

For the students, it can give them more knowledge and skills that will help them in their studies and their daily lives. It can also help them to boost their self-confidence and be motivated in doing whatever they do.

For the parents, they can gain knowledge about the study and know how they can respond and support their children regarding school activities particularly pageantries.

For the teachers, they can find effective ways to help students to participate more in both academic and extracurricular tasks.

\section{References:}

[1]. Buyce, C., (2013) Attribution of pageant experience: participants' self - perceptions of past pageants experiences examined as a communication competence tool. SynaesthesiaCommunication Actors Culture, 2(1), pp 159-178, https://www.synaethesiajournal.com...PDFSynnaethesia-synaesthesia

[2]. Crawford, M., Jha, P., Khati, D., Regmi., (2008) Globalizing beauty: attitudes toward beauty pageants among Nepali women feminism and psychology, 18(1), DOI; 10_1171/0950353507084953

[3]. Fitria, R. \& Salwa (2018). Student's perception of English oral communication usage during practice learning program. Innovish Journal, 3(2). https://media.neliti.com/media/publications/269096-students-percetions-of English-oral-com-72654786.pdf\&ved

[4]. Martinnez, A., Macmahon, S. D., Coker, C. \& Cohen, J., (2016). Involvement in extracurricular activities: identifying differences in perception of school climate, The Education and Developmental Psychologist, 33(1), pp 70-84. DOI: 10.1017/edp 2016.

[5]. Ahmad, M., Rahman, M.F., Ali, M., Rahman, FN. \& Al-Azad Mas (2015) Effect of extra-curricular Activities on Students Academic Performance JAFML Bangladesh, https://www.bandlajol.info/index.php/JAFMC/article/view/39822/30012

[6]. Hermansah, B., (2018). Perceptions of students' parents in activity of extra - curricular ball hand in LPKA class|Pakjo. International Journal of Scientific \& Technology Research., 7(8).https://www.ijstr.org/finalprint/aug2018/Perception-Of-Students-Parents-In-Activity-Of-Extracurricular-Ball-Hand-In-Lpka-Class-Pakjo.pdf\&ved

[7]. Bakoban, R.A. \& Aljarallah, S.A. (2015) Extra-curricular activities and their effect of the students' grade point average. Academic Journals. 10(20),2737-2744. DOI:10.5897/ERR2015.2436

[8]. Tanner, B. (2017) Effects of extra - curricular activities and physical activity on academic success. Intuition; The BYU Undergraduate Journal Psychology, 12(2), 157-168. https://Scholarsarchive.byu.edu/intuition

[9]. Foreman, E.A. \& Retallick, M. (2012) Undergraduate involvement in extra - curricular activities and leadership development in college of agriculture and life sciences students. DOI:10.5032/jae.2012.0311

[10].Gavrilova, E. \& Trostina, K. (2017) Students perceptions of extra - curricular activities in foreign languages as value for their professional competencies developmental and future employment. DOI: https://dx.doi.org/10.12955/cbup.U5.993

[11].Fischer, N., Radisch, F. \& Shcupbach, M. (2014), International perspectives on extra-curricular activities: conditions of effects on student development, communities and schools. Journal for Educational Research Online 6(3), 4-9. https://www.pedocs.de/volltexte/2014/9684/pdf/JERO_2014_3_Fischer_et_al_Editorial.pdf

[12].Lunenburg, $\quad$ F.C., (2010) Extra-curricular activities. Schooling, 1(4). https://www.nationalforum.com/Electronic\%2520Journal\%2520Volumes/Lunenburg,\%2520Fred\%2520C\%2 520Extra-curricular Activities\%2520Schooling\%2520V1\%2520N1\%25202010.pdf\&ved 
[13].Kim, J. \& Bastedo, M. (2016) Athletics, clubs or music? The influence of college extra-curricular activities on job prestige and satisfaction. Journal of Education and Work. DOI: 10.1080/13639080.2016.1165341

[14].Koh, J. N. S. (1987) Extra-curricular activities in schools: getting the right perspective. Institute of Education (Singapore). Teaching and Learning, 7(2) 57-66. https://repository.nie.edu.sg/bitstream/10497/1943/1/TL-72-57.pdf

[15].Jayanthi, V., Balakrishnan, S., Lim Siok Ching, A., Abdul Latiff, N.A. \& Nasidureen (2014) Factors contributing to academic performance of students in a tertiary institution in Singapore. American Journal of Educational Research, vol. 2, no. 9 (2014): 752-758. DOI: 10.1269/education-2-9-8

[16].Al-Sahara, I., (2015). Learning and teaching between enjoyment and boredom as realized by the students: a survey from the educational field. European Scientific Journal, 11(19), https://www.researchgate.net/publication/280579886

[17].Kwon, K. (2018). Students' perception of extra - curricular activities: a case study. Journal of Advances in Educational Research, 3(3), 130-141. DOI:10.22606/jaer.2018.33002

[18].Seow, P.S. \& Pam, G. (2014) A literature review of the impact of extra-curricular activities participation on students' academic. SMU Institutional Knowledge at Singapore Management University. DOI: https://doi.org/10.1080/088323232014.912195

[19]. Acar, Z. \& Gunduz, N. (2017) Participation motivation for extracurricular activities: Study on primary school students. Universal Journal of Educational Research 5(5): 901-910, 2017. DOI: 10.131189/ujer.2017050533

[20].Annu, S. \& Sunita, M. (2015) Extracurricular activities and students' performance in secondary school of government and private schools. International Journal of Sociology and Anthropology Research, Vol. 1, No. 1, pp 53-61. http://www.eajournals.org/wp-content/uploads/Extracurricular-Activities-and-Student---sPerformance-in-Secondary-School-of-Government-and-Private-Schools.pdf

[21].Lozano, J. (2016) Extracurricular engagement of the students of fort san pedro national high school. International Journal of Scientific and Research Publications, Vol. 6, Issue 10, 417-418. http://www.ijsrp.org/research-paper-1016/ijsrp-p5860.pdf

[22].Leung, S. \& Wong, H., (2017) Students' perceptions on joining co-curricular activities: empirical study in hong kong. International Journal of Education. 140.https://www.academia.edu/34616468/STUDENTS_PERCEPTIONS_ON_JOINING_COCURRICULAR_ACTIVITIES_EMPIRICAL_STUDY_IN_HONG_KONG

[23].Mulrooney, H.M. (2017). Exploring participation in co-curricular activities among undergraduates students. New Directions in the reaching of Physical Sciences. 42(1). http://files.eric.ed.gov/fulltext/EJ1231965.pdf

[24].Daniyal, M., Hassan, A., Nawaz, T., \& Mubeen, I. (2012) The effects of extra-curricular activities on the academic performances of students: A case study of the Islamia University of Bahawalpur, Pakistan. Bulgarian Journal of Science and Education Policy(BJSEP), 6(2), 256-272. https://www.researchgate.net/publication/236877916

[25].Ali, N., Ayaz, M., Ullah Shah, R., Khan, A.B., Ahmad, T. \& Andaz Khan G. (2018) Impact of co-curricular activities on students' academic achievement at secondary school level in southern districts of Khyber Pakhtunkhwa. Sci. Int (Lahore), 30(1),63-66. http://www.sci-int.com/pdf/636541578709204805.pdf

[26].Rathore, K., Chaudry, A.Q. \& Azad, M. (2018) Relationship between co-curricular activities and exam performance: mediating role of attendance. Bulletin of Education and Research, Vol. 40, No. 1 pp 183-196. https://eric.ed.gov/?id=EJ1210004

[27].Ruvalcaba, N., Gallegos, J., Borges, A. \& Gonzales, N. (2015) Extra-curricular activities and group belongings as a protective factor in adolescence. PsicologiaEducativa, 23,45-51. https://www.sciencedirect.com/science/article/pii/S1135755X16300318

[28].Kiken, L., (2017). Being present and enjoying it: dispositional mindfulness and savoring the moment are distinct, interactive predictors of positive emotions and psychological health mindfulness. DOI: 10.1007/512671-017-0704-3

[29].Hall, A. (2009) Perceptions of the authenticity or reality programs and their relationships to audience involvement, enjoyment and perceived learning. Journal of broadcasting and electronic media. DOI: $10.108 / 088381509033-$ 10468

[30].Anderson, L.W., Krathwohl, D.R., Airasian, P.W., Cruikshank, K.A., Mayer, R.E., Pintrich, P.R., Raths, J., Simpson E.J. \& Wittrock, M.C. (2001). A taxonomy for learning, teaching, and assessing: a revision of bloom's taxonomy of educational objectives. www.nwlink.com/-donclark/hrd/bloom.html 